\title{
The Status and Future of Korean Computer-aided Publishing Industry: Focused on the publishing markets
}

\author{
Hannah Lee \\ Graduate School of Global Cultural Contents, \\ Hankuk University of Foreign Studies, \\ 107 Imun-ro, Dongdaemun-gu, Seoul, Korea; \\ Jongoh Lee \\ Graduate School of Global Cultural Contents, \\ Hankuk University of Foreign Studies, \\ 107 Imun-ro, Dongdaemun-gu, Seoul, Korea;
}

\begin{abstract}
In the present article, we analyze Korean computer-aided publishing (CAP) market which is growing large in the digital age. Since the Korean market is reorganized into various areas, we examine current conditions and issues of it and discuss several suggestions for the development of Korean CAP industry. The main issues of Korean CAP industry are the conventional images concerning publication, the lack of human resources specialized in CAP, and insufficient platform or viewer for E-books. Grounded on the research results, we suggest five points to develop Korean publication industry. Endeavor of publishing circle is required for the most. The government should reflect the issues and suggestions to the policies and also publishing circle should work with the government with positive and future-oriented attitude.
\end{abstract}

Keywords: status of publication industry, publishing contents, computer-aided publishing, publishing markets, Korea, USA

\section{Background and Objectives}

\section{INTRODUCTION}

Publication is the source of the culture including information, knowledge, wisdom and sensibility, and publishing culture of each country encompassing book and reading conventions implies its cultural entity. However, there is an underlying assumption in Korea that the publishing industry is declining and reading conventions is not established. It is undeniable that publication is the central medium and the basis of development of human culture and knowledge. At the end of the 1400s, printing machine made possible rapid knowledge dissemination and it accelerated the Industrial Revolution. After the information revolution, the Industrial Revolution is ready to step up to the so-called knowledge revolution, the Fourth Industrial Revolution. E-book, the combination of digital technologies and paper book, is in the middle of the social interest because its influence is not known yet. In 2007, Apple's iPhone first appeared in Korea and the change of media has influenced greatly on Korean publishing industry. Globally, publishing industry is showing intense changes. Convergence and transition of media are driven following digital trends, so the whole culturerelated industries are shaking. Publication, the core of culture-related industries, is facing critical turning point.

It is expected that 2018 will be a meaningful year for the publishing market of USA and UK. American consulting company Price Waterhouse Coopers (PWC) anticipates the volume of E- 
book market in USA and UK will exceed that of paper book in 2018. However, the growth of Ebook market in non-English speaking countries like German and Japan is slower than USA and UK. Also Korea is not exceptional. The mass media predicted the lead of E-book in the market with various statistics, but the prediction is not right so far. Ten years passed from 2007, but Korean E-book market is still at stake. Is it a natural flow that paper book is replaced by E-book because of technology development and cultural changes?

Newspaper and publication in Korean media industry show the lowest growth rate. If we consider E-book as a part of publication, the exterior conditions are not so favorable for E-book to haul the whole publishing market. Unlike USA or China where E-book is well used, Korean Ebook market does not show remarkable movement. The sales of E-book reader is stalling and the number of contents available in E-book format has not increased much. American CAP market holds 30\% of the world CAP market and Amazon.com holds 70\% of American market. First we analyze Amazon.com's various sales detail and then examine Korean market reorganized by CAP. The purpose of this article is making suggestion for the development of Korean E-book based on the analysis.

\section{Research Object and Method}

The research object and method of this article are below. First, we analyze Amazon.com's sales detail which holds $70 \%$ of American publishing market to understand current E-book publishing status. Second, Publication Industry Promotion Agency of Korea issued a report on Korean publishing industry's current status. Therefore, we examine the current status with the report and discuss the issues and implications. The study follows orders below. First, we analyze American publishing market's current status. Second, we analyze Korean publishing market's current status. Third, we discuss the issues and implications of Korean publishing market. Fourth, we make suggestion for the development of Korean publishing market.

\section{THE ENVIRONMENT AND TREND OF AMERICAN PUBLISHING INDUSTRY}

Association of America Publishers (AAP) said that American E-book sales during January to September of 2016 decreased $18.7 \%$ while paper book sales increased $7.5 \%$ during the same period. Using this statistics, many Korean mass media asserted that there is no more growth in American E-book market like in Korean under the title such as 'E-book falls and paper book rises again' and 'E-book's fame withering, paper book spot-lighted again.' However, Authorearnings.com's statistics showed interesting results that Amazon.com and other E-book distributors' E-book sales kept increasing.

The reasons of this contradiction is that AAP report was based on the member companies' Ebook sales. Also big E-book distributors like Amazon.com do not open the precise E-book sales status and E-book by indie writers does not attain ISBN. Therefore AAP report about E-book sales decrease is an incomplete report that did not see the market flow correctly. In the current American E-book market, the unit sales market share of indie writers is way higher than the share of so-called Big 5 (Hachette Book Group, Harper Collins, Macmillan Publishers, Penguin Random House, Simon and Schuster). The main selling platform of indie writers is Amazon.com and $85 \%$ of them depend on the site.

The market share of Amazon.com is 74\% when indie writers' book without ISBN are included. $43 \%$ of E-book currently traded through Amazon.com do not have ISBN. 


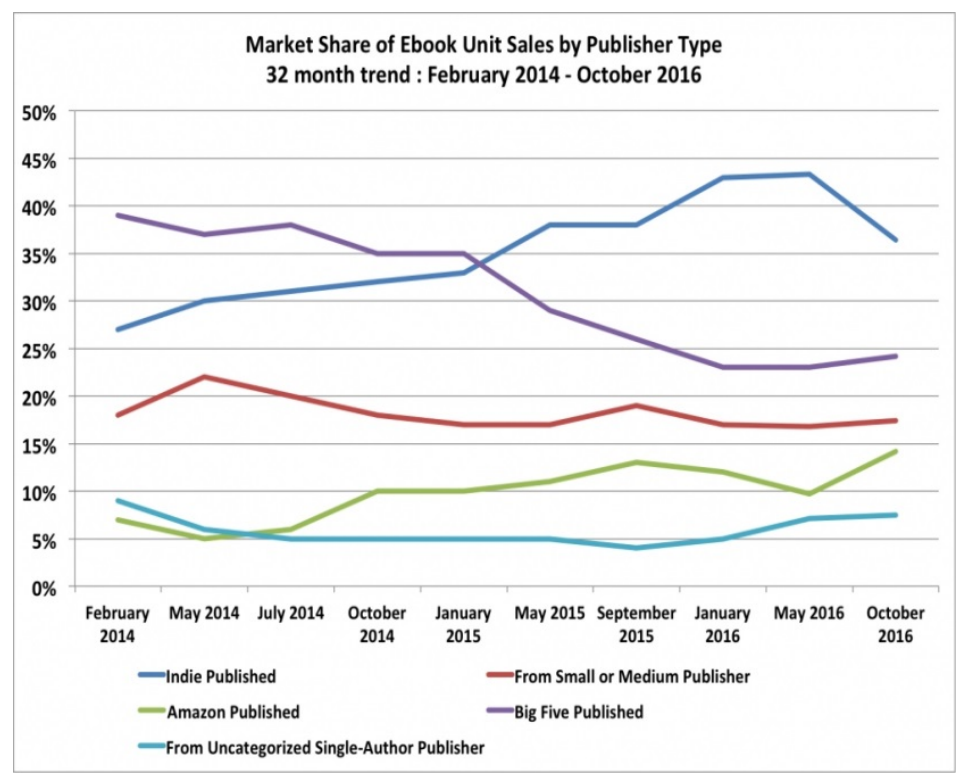

Fig. 1. Source: Authorearnings.com

In Figure1, Big 5's unit sales market share has decreased sharply to 25\% since 2015 and the share of indie publishers has increased constantly to $40 \%$. Big 5 raised the retail price of Ebook after some conflicts with Amazon.com and by Kindle Unlimited's (Amazon.com's E-book unlimited subscribing service) favor, indie publisher E-book unit sales is increasing. However. the total sales revenue of Big 5 is still on top. Small or medium publisher takes the second spot and the next is indie publisher.

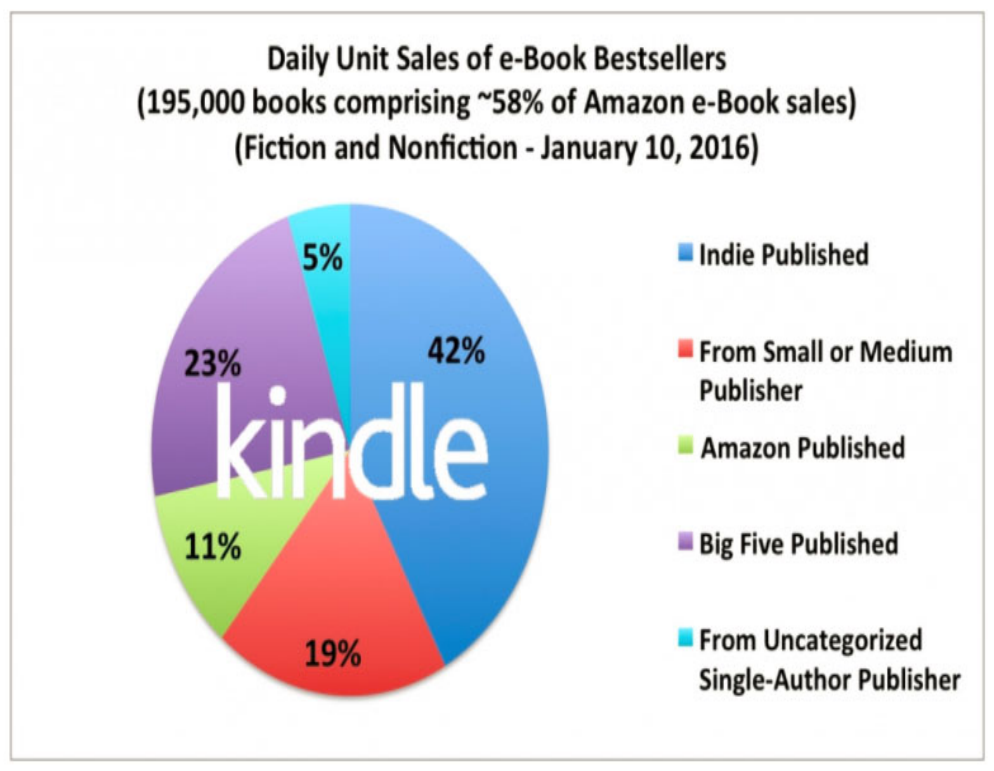

Fig.2. Source: Authorearnings.com

In Figure 2, the most selling publisher type is indie publisher, the second one is small and medium publisher, and the third one is Big 5. It is because of Big 5's retail price rises and the impact of Amazon.com Kindle Unlimited as mentioned before. Also indie publisher and small and medium publisher have advantages in speed, so they grasp the favorite contents of worldwide readers and can publish them soon. From current Amazon.com's sales by genre, romance sales of indie publisher is higher than the sales of Big 5. In 2016, total E-book sales units are 487,298,000 units and about 406,000,000 units, i.e. 83\% are sold through Amazon.com. 
Daily sales units are about 1,064,000 units and about 155,000 units (14\%) are sold through Kindle Unlimited. $45 \%$ of these sales units are E-book format of traditionally published books with ISBN and $43 \%$ are E-books without ISBN. 'Genre fiction' such as romance, mystery, or fantasy is popular both in Korea and USA. This trend would be one of distinct features of Ebook. Even the best E-book reading device cannot replace the sentiment and benefits of paper books. E-book contents are diversified because smart phone's screen is getting bigger and readers using tablet $\mathrm{PC}$ are increasing recently. Average age of the readers who use this kind of devices are tend to be young, so great amount of contents which is currently consumed is categorized as 'genre fiction.'(Ch-B. Kim, 2017)

\section{ENVIRONMENT AND TREND OF KOREAN PUBLISHING INDUSTRY}

Last 10 years, the annual average growth rate of Korean E-book market was constantly around $30 \%$. E-book market has sufficient potential energy to grow bigger. It is global trend that growth potential of digital contents is larger than that of traditional analogue media. However, Korean E-book market does not arrive at maturity yet. In case of USA, an oligopolistic player (i.e. Amazon Kindle) is in market and $20-30 \%$ of the total book market including textbooks has become E-book. Considering American market arrives at its first maturity, Korean E-book market is still unripened.

In 2015, Publication Industry Promotion Agency of Korea calculated E-book distributors' total sales volume as 125.8 billion won. Sales volume of genre fiction (romance, fantasy, martial arts) except web fiction is 57.4 billion won (45.6\%), that of general fiction 35.1 is billion, that of web fiction is 33.3 billion won (26.5\%). The total sales volume has increased $25.4 \%$ year-onyear. and web fiction's sales volume has increased $72.9 \%$ showing the most steep growth. Among the main distributors, one telecommunication company (Onestore) and one portal site (Naver) did not respond to the survey, so their sales volume are excluded. In case we include the estimated sales volume of the two distributors, the total volume of Korean E-book market will be $150-160$ billion won.

Table 1. electronic book distribution business in 2015 (Source: Publication Industry Promotion Agency of Korea)

\begin{tabular}{c|c|c|c|c|c|c}
\hline \multirow{2}{*}{} & \multicolumn{2}{|c|}{$\begin{array}{c}\text { No. of } \\
\text { population }\end{array}$} & \multirow{2}{*}{$\begin{array}{c}\text { Y-O-Y } \\
\text { change }\end{array}$} & \multicolumn{2}{c|}{ Sales volume } & \multirow{2}{*}{$\begin{array}{c}\text { Y-O-Y } \\
\text { change } \\
\text { rate }\end{array}$} \\
\cline { 2 - 3 } & 2014 & 2015 & rate & 2014 & 2015 & \\
\hline $\begin{array}{c}\text { Genre } \\
\text { fiction } \\
\text { (Web } \\
\text { fiction } \\
\text { excluded) }\end{array}$ & - & - & - & 40.246 & 57.385 & 42.6 \\
\hline $\begin{array}{c}\text { General } \\
\text { fiction }\end{array}$ & - & - & - & 40.848 & 35.126 & -14.0 \\
\hline $\begin{array}{c}\text { Web } \\
\text { fiction }\end{array}$ & - & - & - & 19.269 & 33.312 & 72.9 \\
\hline Total & 68 & 21 & -69.1 & 100.363 & 125.823 & 25.4 \\
\hline
\end{tabular}

The big portion of Korean E-book industry is consisted of genre fiction (romance, fantasy, martial arts) and web fiction. The structure of value chain in traditional publishing industry was rather simple. It took over 500 years from Gutenberg's time to build such a simple and highly efficient system, to be precise. However, Internet became popular in 2000s, and the critical point of information dropped sharply. 
Table 2. Sales of the different criteria

(Source: Publication Industry Promotion Agency of Korea)

\begin{tabular}{|c|c|c|c|c|c|c|}
\hline & & $\begin{array}{l}\text { No. of } \\
\text { units }\end{array}$ & $\begin{array}{c}\text { General } \\
\text { literature } \\
(\%)\end{array}$ & $\begin{array}{c}\text { Genre } \\
\text { literature } \\
(\%)\end{array}$ & $\begin{array}{c}\text { Comic } \\
(\%)\end{array}$ & $\begin{array}{l}\text { Magazine, } \\
\text { and others } \\
(\%)\end{array}$ \\
\hline \multicolumn{2}{|c|}{ Total } & 299 & 74.5 & 13.6 & 2.1 & 9.8 \\
\hline \multirow{2}{*}{$\begin{array}{c}\text { Type of E- } \\
\text { book } \\
\text { publishing } \\
\text { company }\end{array}$} & $\begin{array}{l}\text { Based } \\
\text { on } \\
\text { paper } \\
\text { book }\end{array}$ & 250 & 75.9 & 11.9 & 2.2 & 10.1 \\
\hline & $\begin{array}{l}\text { Based } \\
\text { on E- } \\
\text { book }\end{array}$ & 49 & 67.5 & 22.2 & 1.8 & 8.4 \\
\hline \multirow{4}{*}{$\begin{array}{l}\text { Type of } \\
\text { main } \\
\text { contents }\end{array}$} & $\begin{array}{c}\text { Genre } \\
\text { text }\end{array}$ & 46 & 16.8 & 80.8 & 2.4 & 0.0 \\
\hline & $\begin{array}{c}\text { General } \\
\text { text }\end{array}$ & 192 & 97.1 & 1.8 & 0.0 & 1.1 \\
\hline & $\begin{array}{l}\text { Multim } \\
\text { edia }\end{array}$ & 32 & 88.1 & 0.0 & 2.5 & 9.4 \\
\hline & $\begin{array}{c}\text { Others } \\
\text { (Webto } \\
\text { on) }\end{array}$ & 29 & 1.6 & 0.0 & 15.1 & 83.3 \\
\hline
\end{tabular}

Traditional publishing companies rarely issue E-books that originally designed for E-book only. The types of literature comparably holds high portion in paper book based companies and Ebook based companies are, respectively, general literature (75.9\%) and genre literature (22.2\%). The highest sales units according to the type of contents in E-book based companies is textual E-book which is $90.7 \%$. The next are interactive/multimedia E-book $5.5 \%$ and audio book 2.3\%. The textual E-book sales portion of paper book based companies and E-book based companies are, respectively, $91.8 \%$ and $85.3 \%$. In the main contents types, the textual E-book sales portion are genre literature $91.5 \%$ and general literature $90.0 \%$. In multimedia E-book (children, language, learning) 12.5\%, and others (webtoon) 12.1\%, interactive/multimedia type is higher than other types.

\section{ISSUES AND IMPLICATIONS OF KOREAN PUBLISHING MARKET}

\section{Publishing market reorganized by CAP}

In previous section, we examine Amazon.com's sales status and there are unfamiliar new terms such as indie publishing, independent publishing, or self-publishing. These terms also appear in Korean publishing market, but the usage is not entirely same. The terms need to be clarified for further development of Korean market.

First of all, what is indie publishing? The term 'indie' used in Korea and in USA refers different notion. In Korea, many readers and consumers think indie publishing is a form of independent publishing. In USA, however, indie publisher means small publishing companies other than Big 5. Most of the one-person-publishing companies in Korea are indie publishers. The term 'indie' is both used in Korean and American market, but the meaning differs whether one sees it on cultural side or industrial side. Second, independent publishing is a part of 'indie culture' which focuses on creative and experimental music or art, unlike the established mainstream culture. 
Therefore, indie culture of the publishing circle is independent publishing. To be precise, a book needs to attain ISBN (International Standard Book Number) to sell at traditional bookstores.

A publishing company has to register ISBN with a completed book to the National Library of Korea. All books on the market have their individual ISBN. However, independent publishing does not register ISBN. This is the fundamental point where independent publishing and traditional publishing diverges. Basically all publishing products freely made by an individual who does not belong to any publication corporation are called independent published. Jiwon Cheon is running an independent publishing bookstore and says, "Unlike commercial publishing, the first purpose is not a profit but letting others know what I think."

Third, self-publishing is that authors publish by themselves. Publishing through various web fiction platform such as Munpia, Joara, or Kakaostory, and publishing by Daum, Webtoon are self-publishing. Publishing market is critical on the biggest web fiction publishing platforms like Munpia and Joara, except the portal sites. However, if we apply market logic to Korean market where consumers usually do not spend money on the contents, the phenomenon that total revenue went over 10 billion won only with the text based contents implies many things. Academies for those who want to publish their own stories are easy to find, and especially Ebook making platform for those who wants to publish independently is available. Due to the progress of E-book technology, the environment for direct contents producing, designing and editing is created. Also webtoon of large portal sites (Naver, Daum) and web fiction sites (Kakaostory, Munpia, Joara) are interesting. Although most of the contents are not published in form of books, many people consume the contents which have high possibility to be published. As a result, annually the market having tens of billions won of value is forming and it shows the possibility of online independent publishing. Independent published texts have already been delivered to the readers through diverse paths.

Both Korean and American publishing markets are reorganized by CAP into multiple types.

\section{Self-publishing: Growth of web fiction market}

One of important parts of the E-book publishing industry is web fiction market. Not only in USA but also in Korea, genre fiction such as romance, mystery, or fantasy is growing bigger. This trend would be one of distinct features of E-book. E-book contents are diversified because smart phone's screen is getting bigger and readers using tablet PC are increasing recently. Average age of the readers who use this kind of devices are tend to be young, so great amount of contents which is currently consumed is categorized as genre fiction. The influence of web fiction to E-book market is remarkable.

Growth of the sites like Munpia and Joara shows the phenomenon. Joara started its service from early 2000 and has provided the gateway for speculative pulp fiction or light novel writers. Joara is still active and took first prize at Korean web fiction site brand research in 2016. Unlike other web fiction sites selecting writers through contests, anybody can write on Joara, so certain amount of web fiction is constantly posted. There is critical perspective on web fiction that does not consider it as a form of publishing. The first reason is question on the contents quality. In fact, setting up a standard for contents quality is impossible, but the quality problem may be the reason why pure literature devalues genre literature.

It is time to expand the notion of publication in Korean publishing market, rather than to deny web fiction as a publication. The judgement on contents quality is left for the consumers who actually spend money. As we mentioned already, the top of Amazon.com daily unit sales of E- 
book bestseller by publisher type is indie publishers, and the next are small or medium publishers, and Big 5. At Amazon.com sales revenue by genre, indie publishers' sales revenue of romance outnumbers Big 5's. Competence trying to publish paper book format of popular web fiction is also necessary.

In American market, due to the huge online distributor Amazon.com, indie publishing, independent publishing, and self -publishing appear and they show the new types of E-book market. In Korea, one-person-publishing company is indie publisher and various $s$ web platforms like Joara, Munpia, Kakaostory provide the media for self-publishing. Furthermore, many independent magazines and independent publishing texts are distributing through independent bookstore or social media.

\section{CONCLUSION}

As shown above, theoretical perspectives on urban regeneration has logical and empirical foundations of respective scholars. Theories on urban regeneration are explained by dividing into theories of scholars and theories of types. Once people imagine the time E-book eat up all the paper books and the end of paper comes. Clearly, paper books never vanish from the bookshelves overnight. Korean E-book starts to settle down mainly with light fiction like martial arts and romance and it is similar to American market. Appbook, digital magazine, multimedia E-book, and App contents for children are the next steps to enlarge the market base and are diverse figures of future CAP.

The definition of publishing.CAP is differ from country to country, organization to organization, and scholar to scholar. The concept of traditional publishing and that of CAP in the digital media era are also different. The definition of publishing is enlarging and evolving in the aspect of culture, industry, and technology.

However, nobody denies that publishing.CAP is the basic platform of several contents industries. This is the reason why people in the publication industry prepare for the future and embrace it positively. Now, we make few suggestions for the development of CAP market.

First, people in the publication industry are bound by stereotype. It is that publication includes the whole process (plan-edit-design-manufacture-distribution) until the book is released and the publishing company is the only behavior of publishing. However, as we mentioned above, everybody can publish books due to the development of digital technology. We should break the stereotypes by ourselves.

Second, the development of digital technology makes us face the age of E-book and introduces new platform and format. A bookstore publishes serial romance fiction (e-series of Yes24.com) and fantasy fiction posted on the online bulletin sells per episode (Joara). E-book specialized bookstore publishes (Ridibooks Helloworld) and telecommunication company gets tens of billions won profit by selling books (SKT T Store). Portal sites mediate paper book publishing (Naver post, Daum Kakao Brunch) and a publishing company opens crowd funding to issue paper books (Storyfunding, Tumblebug). Each cultural content is delivered to worldwide internet/mobile users by index and hash tag and this one links to that one. The boundary of traditional publication, game, and music break down. Contents are connected by convergence and are designed and produced by themselves following each format. Training professional of each platform and format is also required.

Third, considering contents industry is force of future growth, the government separated publication and contents when they made support policies. However, publication is the main 
platform of contents field such as movie, animation·character, game, music, story·webtoon, fashion, and broadcasting. The age of OSMU (One Source Multi Use) already has come. There are success cases like Harry Potter movie (originally book), Please Look After Mom play (originally book), Misaeng TV drama (originally webtoon), and Secretly, Greatly movie (originally webtoon). The conventional area of publication already fell down and new area of cultural contents is rising. Publication will become a growing industry if the frame of publication expand to planning contents and putting on the media. Publishing industry is contents industry. This is why we call publishers as contents provider. The notion of publication should be enlarged.

Fourth, the ecosystem of publication is well established. Publishing companies should design the structure to support contents and keep the diversity. Publishing companies should suggest to the famous web fiction writers the publishing of paper book and should make the process of cooperation.

Lastly, the government should nurture the publication industry with policies. As E-book market enlarges, the age has come when we do not consider publication as a book but as contents. We should not judge ourselves whether indie publishing, independent publishing, or self-publishing is a type of publishing or not. We should accept the newly reorganized CAP forced by the development of digital technology and wait for the evaluation of the consumers of the contents. Publication is not a declining industry. The development of digital technology reveals through CAP market that publication is the basis of cultural contents and important culture industry. We expect new image of publishing contents, the base of cultural contents by E-book development. The study about the influence of cultural contents and publishing industry in the culture industry is left for follow-up research.

\section{ACKNOWLEDGMENTS}

This work was supported by the Research Fund from Hankuk University of Foreign Studies.

\section{References}

Julie Han, Changes and the future of publishing industry as a medium, The Korean Publishing Science Society, 1, (2012)

Ch-B. Kim, Trend of American Publishing Industry, in K-Book Trends, No.4 (2017).

G-S. Lee and D-H. Jo, Contents e-book publishing, Haenem, (2010)

. H-N. Lee, The publication and OSMU in the age of cultural content, story house, (2011)

S-W. Lee, The Development and Tasks of Web Publication, The Korean Publishing Science Society, 43-2, (2017).

The Electronic Author (2014. 2. 28). "The Market Share of E-Book Retailers",

(http://www.electronicauthor.com/2014/02/the-market-share-of-e-bo ok-retailers/)

http://wl.nl.go.kr/user/0042/nd24524.do?View\&uQ2\&uQ\&pageST=SUBJECT\&pageSV\&page=1\&pageSC=SORT_0 RDER\&pageSO=DESC\&dmlType\&boardNo=00005442\&siteLink\&menuCode $=$ www\&zineInfoNo $=0042$

http://authorearnings.com/report/october-2015-apple-bn-kobo-and-google-a-look-at-the-rest-of-the-ebookmarket/Foracchia, M., Extraction and quantitative description of vessel features in hypertensive retinopathy fundus images, in Book Abstracts 2nd Int. Workshop on Computer Assisted Fundus Image Analysis, E. Grisan, Editor 2001. p. 6-6. 